\title{
Case report: Osteomalacia due to bisphosphonate treatment in a patient on hemodialysis
}

Masaki Hatano ${ }^{1 *}$ D, Izuru Kitajima', Seizo Yamamoto ${ }^{1}$, Masaki Nakamura', Kazuya Isawa', Yutaka Hirota', Junichi Hoshino ${ }^{2,3}$, Naoki Sawa ${ }^{2,3}$ and Yoshifumi Ubara ${ }^{2,3^{*}}$

\begin{abstract}
Background: No publications have reported on osteomalacia in patients receiving intermittent cyclical therapy with etidronate (a bisphosphonate) and undergoing long-term hemodialysis (HD).

Case presentation: We report on a 46-year-old Japanese man admitted to our hospital for further examination of left forearm pain. Maintenance HD was started at age 24 years, and the man had been on HD since then. At age 38 years, surgical parathyroidectomy was performed for secondary hyperparathyroidism; iliac crest bone biopsy performed at the same time showed osteitis fibrosa. The active vitamin $D_{3}$ preparation calcitriol was started, and intermittent cyclical etidronate therapy was introduced 2 years later for osteoporosis. At age 45 years, the patient stopped taking calcitriol because of hypercalcemia but continued with etidronate. At age 46 years, a pseudofracture with a Looser zone occurred in the left ulna, and left femur bone biopsy revealed osteomalacia. Etidronate was discontinued, and calcitriol was restarted; open reduction and internal fixation with an angular stability plate were performed. Union of the bone was achieved 10 months after the operation. At age 49 years, a lumber bone biopsy confirmed improved bone morphometry.

Conclusions: We believe that intermittent cyclical etidronate therapy without administration of active vitamin $D_{3}$ during long-term HD might have induced osteomalacia, resulting in the ulna insufficiency fracture. Therefore, we propose that administration of active vitamin $\mathrm{D}_{3}$ is essential to prevent osteomalacia in patients on long-term $\mathrm{HD}$ who are receiving bisphosphonates and have potential vitamin $\mathrm{D}_{3}$ deficiency.
\end{abstract}

Keywords: Bisphosphonate, Bone histomorphometry, Etidronate, Hemodialysis, Osteomalacia, Case report

\section{Background}

Mineral abnormalities related to renal osteodystrophy (ROD) are common in patients with chronic kidney disease (CKD) [1]. The gold standard for the diagnosis and specific classification of ROD is bone biopsy with bone histomorphometry [2]. A bone biopsy is recommended

\footnotetext{
* Correspondence: hm0523jp@yahoo.co.jp; ubara@toranomon.gr.jp 'Department of Orthopaedic Surgery, Toranomon Hospital Kajigaya, 1-3-1 Kajigaya, Takatsu, Kawasaki, Tokyo, Kanagawa 212-0015, Japan

2Department of Nephrology Center, Toranomon Hospital Kajigaya, 1-3-1, Takatsu, Kawasaki, Tokyo, Kanagawa 212-0015, Japan

Full list of author information is available at the end of the article
}

if results will guide treatment decisions, and is therefore advised in cases of unexplained fractures and bone pain, and may be considered prior to PTX or starting antiresorptive treatment. However, a bone biopsy is not well suited to monitor treatment response in cases of frequent changes, as bone is a slow-reacting tissue.

Bisphosphonates (BPs) are bone antiresorptive agents that are widely used to treat postmenopausal or glucocorticoid-induced osteoporosis. The current Kidney Disease: Improving Global Outcomes (KDIGO) recommendations limit their use in patients with renal

(c) The Author(s). 2021 Open Access This article is licensed under a Creative Commons Attribution 4.0 International License, which permits use, sharing, adaptation, distribution and reproduction in any medium or format, as long as you give appropriate credit to the original author(s) and the source, provide a link to the Creative Commons licence, and indicate if changes were made. The images or other third party material in this article are included in the article's Creative Commons licence, unless indicated otherwise in a credit line to the material. If material is not included in the article's Creative Commons licence and your intended use is not permitted by statutory regulation or exceeds the permitted use, you will need to obtain permission directly from the copyright holder. To view a copy of this licence, visit http://creativecommons.org/licenses/by/4.0/ The Creative Commons Public Domain Dedication waiver (http://creativecommons.org/publicdomain/zero/1.0/) applies to the data made available in this article, unless otherwise stated in a credit line to the data. 
impairment because of concerns about worsening renal function, bone mineralization defects, and osteomalacia. However, the pathogenesis of osteomalacia due to BPs in HD patients remains unclear. Currently, no publications report on osteomalacia due to BPs in patients on long-term HD. Here, we describe a patient on long-term HD who received intermittent cyclical etidronate therapy after parathyroidectomy (PTX) and developed osteomalacia after discontinuing active vitamin $\mathrm{D}_{3}$ derivative.

\section{Case presentation}

A 46-year-old Japanese man on HD for 22 years was admitted to our hospital for further examination of left forearm pain. Maintenance dialysis was started at age 24 years after bilateral nephrectomy for hemorrhagic angiomyolipoma related to tuberous sclerosis. At age 38 years, the patient developed severe bone pain without any precipitating cause, and bilateral Achilles tendon rupture was noted (Fig. 1A). Because secondary hyperparathyroidism (with an intact parathyroid hormone [PTH] level of $1630 \mathrm{pg} / \mathrm{mL}$ ) resistant to conservative treatment was considered a causative factor, surgical PTX was performed with autotransplantation into the subcutaneous tissue of the non-shunt side forearm. The iliac crest bone was biopsied at the same time and bone histomorphometric analysis was performed at the Ito Bone Science Institute, Niigata, Japan. Tetracycline double labeling was also performed with doxycycline at $200 \mathrm{mg}$ daily (with a schedule of 3 days on, 12 days off, 3 days on, 13 days off). Osteitis fibrosa was diagnosed, with a fibrous tissue volume to total volume (Fb.V/TV) of $9.1 \%$ ( $>0.5 \%$ required for diagnosis) and an osteoid volume to bone volume $(\mathrm{OV} / \mathrm{BV})$ of $13.0 \%(<15 \%$ required for diagnosis according to the Sherrard et al. classification of ROD) [3]. Double labelling by tetracycline showed a bone formation rate per unit of bone volume (BFR/BV) of $120.2 \%$ per year, indicating a high bone turnover. Bone is resorped by osteoclasts and formed by osteoblasts, and normally these 2 processes progress at the same time and rate; in our patient, the higher bone turnover resulted in woven bone characterized by haphazardly organized collagen fibers (Fig. 2A).

After PTX, the intact PTH level was less than $100 \mathrm{pg} /$ $\mathrm{mL}$, so the patient was prescribed calcium lactate $(3.0 \mathrm{~g} /$ d) and active vitamin $\mathrm{D}_{3}$ (calcitriol, $0.5 \mu \mathrm{g} / \mathrm{d}$ ) to treat hungry bone syndrome. The bilateral Achilles tendon rupture healed. Two years after the surgical procedure, low bone mineral density was diagnosed (T-score of 3.1 measured by dual energy X-ray absorptiometry [DEXA]) and intermittent cyclical etidronate therapy ( $200 \mathrm{mg} / \mathrm{d}$ for 2 weeks every 4 months) was started; calcitriol was continued. At age 45 years, calcitriol was stopped because of hypercalcemia, and at age 46 years the patient developed left forearm pain for no obvious reason that worsened by the day. One week later, a radiograph showed a pseudofracture with a Looser zone in a proximal portion of left ulna; the pseudofracture manifested as a $3 \mathrm{~mm}$-wide radiolucent band perpendicular to the bone surface (Fig. 1B). Therefore, the patient was admitted to our hospital for surgical treatment.

On admission, the patient was $174.0 \mathrm{~cm}$ tall and weighed $79.5 \mathrm{~kg}$. Blood levels (Table 1) were as follows: the patient had PTH in target range, with normal calcium, high phosphate levels and lower 1.25-dihydroxy vitamin $\mathrm{D}_{3}$.

Bone scintigraphy with ${ }^{99 \mathrm{~m}}$ Tc-labeled methylene diphosphonate showed intense uptake in multifocal regions, including multiple ribs, costochondral junctions, costovertebral junctions, and both posterior iliac bones, as well as in the affected left ulna; these findings are characteristic of osteomalacia (Fig. 1C).

Open reduction and fixation with an angular stability plate and left total knee arthroplasty were performed. At the same time, left femur bone biopsy was performed to identify the pathogenesis of the ulna pseudofracture. Bone histomorphometric analysis was performed at the Ito Bone Science Institute (Niigata, Japan). Tetracycline double labeling was not performed.

Cancellous bone was assessed by bone histomorphometry (Table 2). The trabecular bone volume (BV/TV) was within the age-matched reference range according to the report by Reccker et al. [4]; however, the trabecular thickness (Tb.Th) was lower than at the first bone biopsy $(93.4 \mu \mathrm{m})$. All osteoid markers were increased compared with the first bone biopsy, parameters of bone resorption were decreased (Fig. 2B). Osteomalacia was diagnosed according to Sherrard's classification of ROD [3] because the Fb.V/TV was $0.1 \%(<0.5 \%$ required for diagnosis) and the OV/BV was $40.7 \%$ ( $>15 \%$ required for diagnosis). The number of osteoclasts (N.Oc/BS) was decreased to $0.148 \mathrm{~N} / \mathrm{mm}$, and the number osteoblasts surface (Ob.S/BS) was $12.3 \%$.

A deficiency in 1,25-dihydroxyvitamin $\mathrm{D}$ was found, and we assumed that this deficiency, combined with administration of etidronate in a condition of lower PTH levels after PTX, might have contributed to mineralization disturbance-related osteomalacia and resulted in the formation of multiple pseudofractures, including a Looser zone because bone disease manifested 1 year after calcitriol was stopped. Therefore, calcitriol was restarted at a dose of $0.5 \mu \mathrm{g} / \mathrm{d}$ and etidronate was discontinued. Ten months later, the Looser zone had disappeared and bone union was achieved (Fig. 1B).

At age 49 years, a surgical procedure was performed for lumbar destructive spondyloarthropathy related to beta 2 microglobulin amyloidosis resulting from longterm HD, and a lumber bone biopsy was performed at the same time. Bone histomorphometric analysis was 


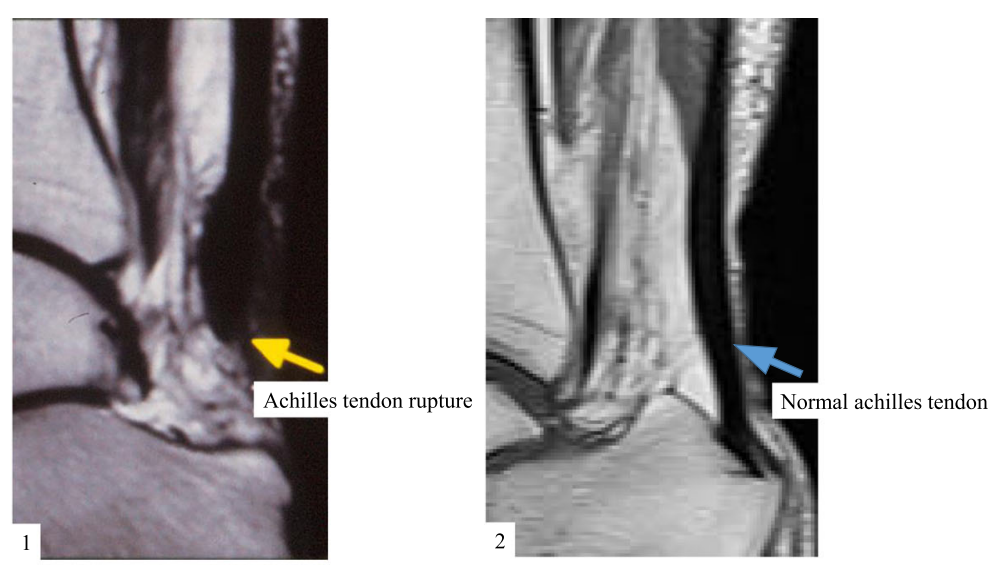

A

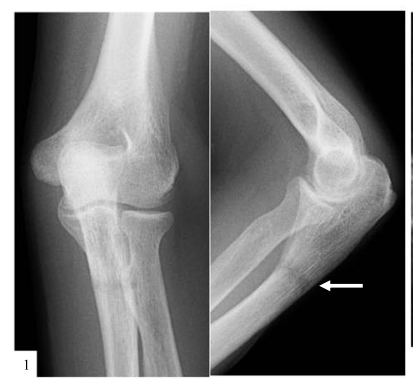

Lateral view
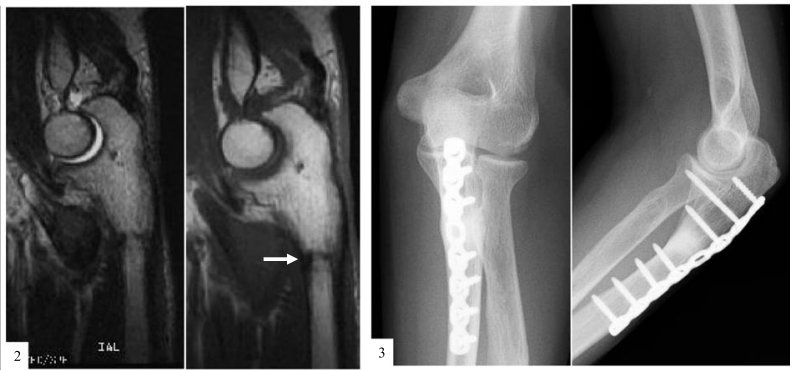

T2-weighted

T1-weighted

Anteroposterior view

Lateral view

$\mathrm{B}$
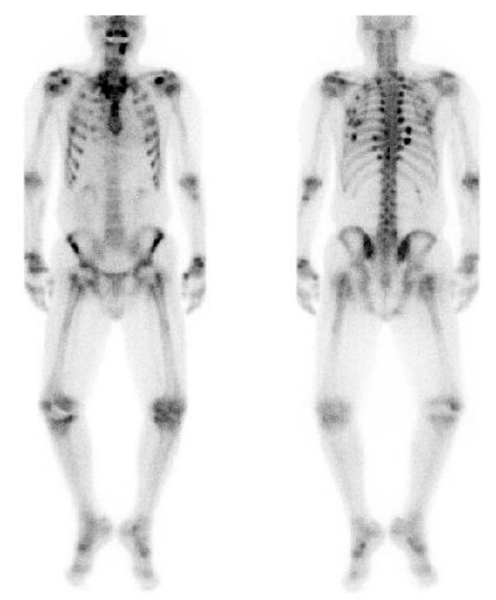

$\mathrm{C}$

Fig. 1 (A) 1 Sagittal t1 magnetic resonance imaging (MRI) shows complete Achilles tendon tear (yellow arrow); 2 Sagittal t1 MRI shows Normal achilles tendon (blue arrow). (B) 1 Anteroposterior and lateral radiograph of the left ulna shows left ulna pseudofracture (white arrows); 2 Sagittal T1 and T2 weighted images in MRI show low band in the bone; 3 Successful bone union. (C) Bone scintigraphy revealed multifocal lesions, including multiple ribs, costochondral junctions, costovertebral junctions, and both posterior iliac bones

again performed at the Ito Bone Science Institute (Niigata, Japan). Tetracycline double labeling was not performed.

At the third bone histomorphometric analysis, all osteoid markers had improved compared with the second biopsy. The abnormal woven bone seen at the first biopsy and abnormal osteoid seen at the second biopsy had disappeared. Normal levels of osteoblasts and osteoclasts were noted. The majority of trabecular bone was occupied by lamellar bone, which is obtained by wellbalanced bone remodeling and indicates new bone formation by osteoblasts arising after bone resorption by osteoclasts. In addition, new bone had been formed by minimodeling, which is characterized by a lack of precedent bone erosion by osteoclasts (Fig. 2C) [5]. 

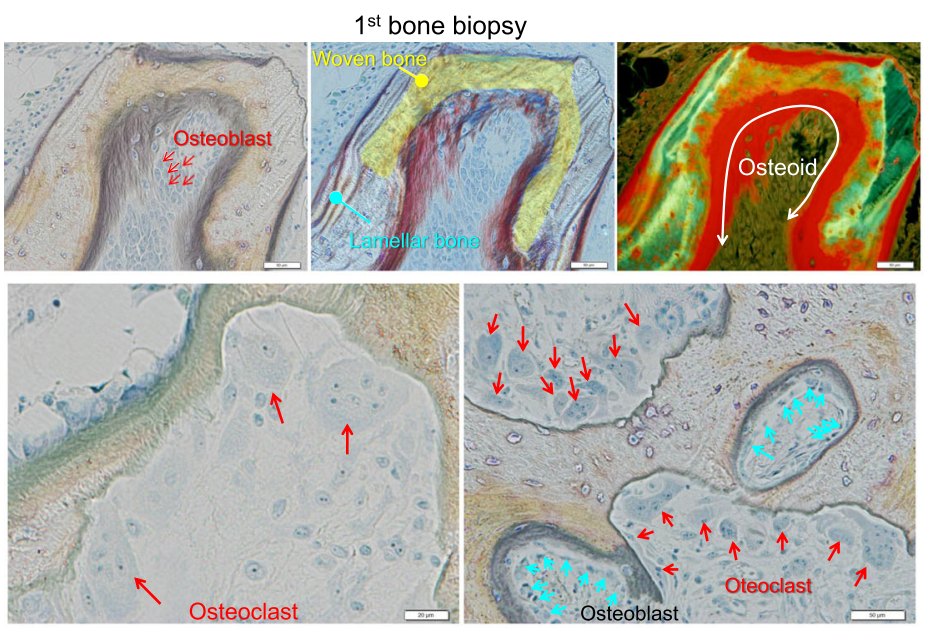

A

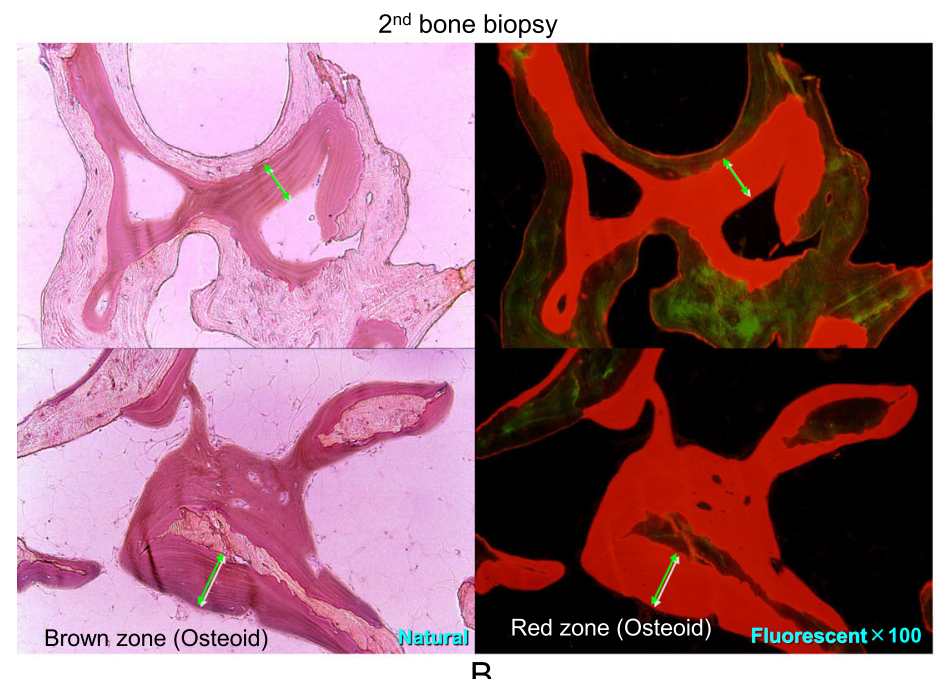

B

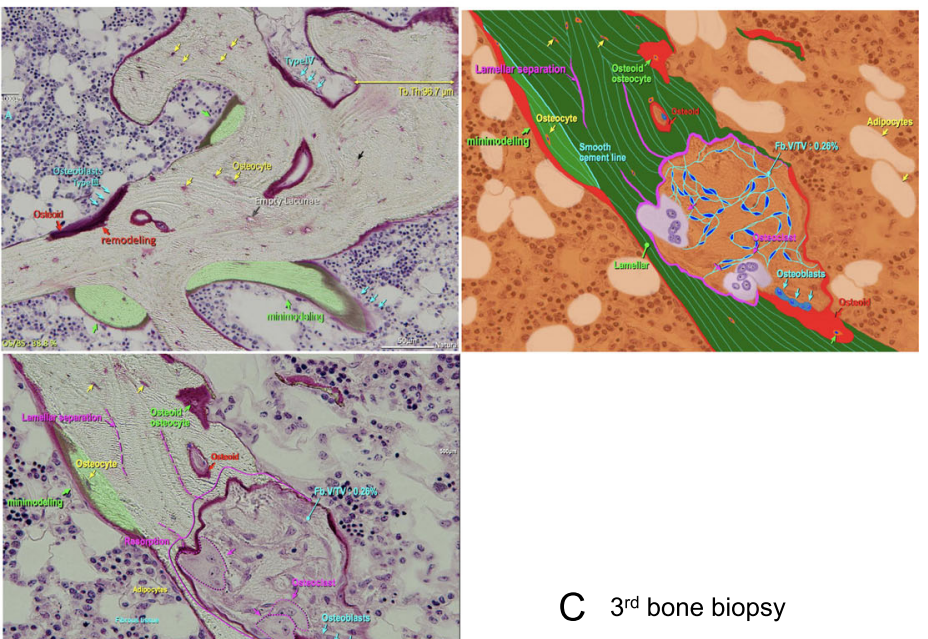

Fig. 2 (See legend on next page.) 
(See figure on previous page.)

Fig. 2 (A) Natural light and fluorescent microscopic analysis of the iliac bone section (1st bone biopsy). Bone resorption by osteoclasts and bone formation by osteoblasts progress at the same time, and woven bone was formed characterized by haphazardly organized collagen fibers. (B) Natural light and fluorescent microscopic analysis of the femoral cortical bone near a cancellous bone section (2nd bone biopsy). An increase in the amount of osteoid was observed, along with increased thickness of osteoid seam width and a low calcification area on the bone surface and in the bone. (C) Analysis of the lumbar spine bone section (3rd bone biopsy). Both remodeling and minimodeling were observed. The majority of trabecular bone was occupied by 2 types of new lamellar bone formation: remodeling, which is characterized by new bone formation by osteoblasts after bone resorption by osteoclasts, and minimodeling, which is characterized by a lack of precedent bone erosion by osteoclasts

Bone mineral density (BMD) assessed by DEXA at the lumbar spine and the forearm were improved (Table 3).

\section{Discussion and conclusions}

These findings indicated that active vitamin $\mathrm{D}_{3}$ replacement induced normal bone formation even though PTH levels were lower after PTX [6].

Chronic kidney disease mineral and bone disorder (CKD-MBD) is a complex disorder of bone and mineral metabolism. Stress fractures are known to be caused by ROD associated with bone fragility and long-term HD $[7,8]$. Therefore, ROD must be evaluated and diagnosed: According to histologic features of biopsied bone, ROD is classified as osteitis fibrosa, osteomalacia, and mixed, mild, and adynamic disease [3]. Generally, BMD is widely used to evaluate osteoporosis; however, it does not predict the type of ROD or accurately evaluate bone fragility in HD patients [9]. KDIGO recommends that bone biopsy should be considered if it will inform treatment decisions [10]. The decision to treat with either antiresorptive or anabolic agents needs to be based on the level of kidney function, bone turnover, and mineralization.
BPs are potent inhibitors of osteoclast-mediated bone resorption. They are widely used to treat postmenopausal or glucocorticoid-induced osteoporosis, but little evidence is available on their effectiveness and safety in patients on HD. Previous studies reported that BPs were a potential treatment for renal osteodystrophy, particularly in patients with high bone turnover or hypercalcemia related to increased release of calcium from bone $[11,12]$, and that they may be beneficial in HD patients $[13,14]$.

BPs are classified into 2 groups with different molecular modes of action: non-nitrogen-containing BPs and nitrogen-containing BPs. Etidronate is a non-nitrogencontaining BP. BPs have several severe adverse effects, including acute renal failure, worsening renal function, reduced bone mineralization, and osteomalacia. The pathophysiological mechanisms by which BPs cause osteomalacia are still unknown. So far, studies have reported that etidronate and clodronate, another non-nitrogen-containing BP, may inhibit bone mineralization [15-17]. Reports on osteomalacia or mineralization defects associated with etidronate therapy were described in patients with Paget's disease who received continuous etidronate therapy at high doses $(17-20 \mathrm{mg} / \mathrm{kg} / \mathrm{d})$. High

Table 1 Laboratory Data. BAP: bone alkaline phosphatase, IGF-1: Insulin-like growth factor 1, NM: no measurement, PTH: parathyroid hormone, PTX: parathyroidectomy

\begin{tabular}{|c|c|c|c|c|c|}
\hline & After PTX & $\begin{array}{l}\text { Second bone } \\
\text { biopsy }\end{array}$ & $\begin{array}{c}\text { Second post operative } \\
\text { year } 1\end{array}$ & Third bone biopsy & Reference range \\
\hline $\mathrm{BAP}(\mu \mathrm{g} / \mathrm{L})$ & NM & 42.6 & 18.8 & NM & $3.7-20.9$ \\
\hline IGF-1 (ng/mL) & 176.72 & NM & NM & NM & $36.9-121$ \\
\hline 1,25-dihydroxyvitamin $\mathrm{D}(\mathrm{pg} / \mathrm{mL})$ & NM & $<4.0$ & NM & $<4.0$ & $20-60$ \\
\hline Osteocalcin $(\mathrm{ng} / \mathrm{mL})$ & 97.3 & 13.3 & 29.6 & 46.7 & $8.4-33.1$ \\
\hline Intact PTH (pg/mL) & $>1630$ & 51.9 & 48 & 78 & $15-65$ \\
\hline Alkaline phosphatase $(\mathrm{U} / \mathrm{L})$ & 3153 & 448 & 289 & 556 & $117-350$ \\
\hline Total protein $(\mathrm{g} / \mathrm{dL})$ & 6.6 & 7.5 & 8 & 7.1 & $6.9-8.4$ \\
\hline Albumin (g/dL) & 3.3 & 3.5 & 3.6 & 3.5 & $3.9-5.2$ \\
\hline Calcium (mg/dL) & 9.4 & 9.7 & 9.8 & 7.6 & $8.7-10.1$ \\
\hline Phosphate (mg/dL) & 5.4 & 5.4 & 5.7 & 6.4 & $2.8-4.6$ \\
\hline Ferum $(\mu \mathrm{g} / \mathrm{dL})$ & 173 & 37 & 114 & 32 & $80-120$ \\
\hline $\begin{array}{l}\text { Unsaturated iron binding capacity } \\
(\mu \mathrm{g} / \mathrm{dL})\end{array}$ & 69 & 316 & 231 & 392 & $173-263$ \\
\hline
\end{tabular}


Table 2 First, second, and third histomorphometric analysis of the iliac crest

\begin{tabular}{|c|c|c|c|c|c|c|c|}
\hline Parameter & & $\begin{array}{c}\text { Ratio or } \\
\text { abbreviation }\end{array}$ & Unit & $\begin{array}{c}\text { Measured value(1st bone biopsy: } \\
\text { iliac bone) }\end{array}$ & $\begin{array}{l}\text { Measured value( } 2 \text { nd bone biopsy: } \\
\text { femur bone) }\end{array}$ & $\begin{array}{c}\text { Measured value(3rd bone biopsy: } \\
\text { Lumber bone) }\end{array}$ & Normal range \\
\hline \multirow[t]{3}{*}{ Bone volume } & Bone volume & BV/TV & $\%$ & 19.7 & 19.3 & 22 & $21.1 \pm 3.2$ \\
\hline & Trabecular thickness & Tb.Th & $\mu \mathrm{m}$ & 108.6 & 93.4 & 96.7 & $144.5 \pm 17.1$ \\
\hline & Wall thickness & W.Th & $\mu \mathrm{m}$ & NM & NM & 45.7 & $43.2 \pm 2.9$ \\
\hline \multirow[t]{5}{*}{ Osteoid } & Osteoid volume & OV/TV & $\%$ & 2.6 & 7.86 & 2.42 & $0.1 \sim 1.0$ \\
\hline & Osteoid volume & OV/BV & $\%$ & 13 & 40.7 & 11 & $4.9 \pm 1.2$ \\
\hline & Osteoid surface & OS/BS & $\%$ & 56 & 56 & 38.8 & $23.2 \pm 3.4$ \\
\hline & Osteoid thickness & O.Th & $\mu \mathrm{m}$ & 12 & 34.9 & 13.4 & $11.6 \pm 2.0$ \\
\hline & Osteoblast surface & Ob.S/BS & $\%$ & 26.5 & 12.34 & 6.78 & \\
\hline \multirow[t]{4}{*}{ Resorption } & Eroded surface & ES/BS & $\%$ & 23.9 & 9.3 & 4.67 & $5.6 \pm 1.7$ \\
\hline & Osteoclast number & N.Oc/TV & N.mm2 & NM & 0.54 & 0.79 & \\
\hline & Osteoclast number & N.Oc/BS & N.mm & 0.9 & 0.148 & 0.17 & \\
\hline & Fibrous volume & $\mathrm{Fb} . \mathrm{V} / \mathrm{TV}$ & $\%$ & 9.1 & 0.1 & 0.26 & 0 \\
\hline \multirow[t]{5}{*}{ Mineralization } & $\begin{array}{c}\text { Mineral apposition } \\
\text { rate }\end{array}$ & MAR & $\mathrm{mcm} /$ day & 0.67 & NM & NM & $0.94 \pm 0.16$ \\
\hline & $\begin{array}{l}\text { Double labeled } \\
\text { surface }\end{array}$ & $\mathrm{dLS} / \mathrm{BS}$ & $\%$ & 12.7 & NM & NM & \\
\hline & $\begin{array}{l}\text { Singlel abeled } \\
\text { surface }\end{array}$ & sLS/BS & $\%$ & 29 & NM & NM & \\
\hline & Bone formation rate & BFR/BS & $\begin{array}{c}\mathrm{mm} 3 / \mathrm{mm} 2 / \mathrm{y} \\
\text { ear }\end{array}$ & 0.065 & NM & NM & \\
\hline & Bone formation rate & BFR/BV & $\% /$ year & 120.2 & NM & NM & \\
\hline
\end{tabular}

doses and continuous therapy with etidronate might induce mineralization defects, although no serious adverse effects were reported with intermittent cyclical etidronate therapy for postmenopausal osteoporosis [18].

Osteomalacia is a bone disease characterized by low bone turnover, defective mineralization, and accumulation of unmineralized osteoid. Traditionally, RODrelated osteomalacia was caused by aluminum toxicity (aluminum inhibits bone mineralization in case of vitamin D deficiency) [3], and osteomalacia caused by iron deposition was frequently found from 1970 to 1990. Hypocalcemia, hypophosphatemia, hypovitaminosis D, toxic effects of drugs are common in patients with CKD $[19,20]$; however, few studies reported finding osteomalacia due to vitamin $\mathrm{D}$ deficiency in $\mathrm{HD}$ patients $[8,21$, 22]. In addition, the effects of vitamin $D$ deficiency in HD patients remain to be clarified.
Our patient started intermittent cyclical etidronate therapy after surgical PTX for severe secondary hyperparathyroidism. After PTX, our patient took the active vitamin $\mathrm{D}_{3}$ preparation calcitriol because of hungry bone syndrome [23]. However, 7 years after PTX calcitriol was discontinued because of hypercalcemia. One year later, the ulna pseudofracture occurred and osteomalacia was diagnosed. In this case, intermittent cyclical etidronate therapy combined with vitamin D deficiency and $\mathrm{HD}$ might have contributed to bone demineralization.

Secondary hyperparathyroidism is a common problem in long-term HD patients. Despite considerable advances in medical therapy for secondary hyperparathyroidism, PTX remains an important therapeutic tool for treating refractory hyperparathyroidism. Surgical PTX is better at preventing recurrence than other surgical therapies [24]. On the other hand, PTX can easily induce hypocalcemia

Table 3 Bone mineral density data. PTX: parathyroidectomy, Spine AP: Spine anterior-posterior, Spine LAT: Spine lateral

\begin{tabular}{|c|c|c|c|c|c|}
\hline & & After PTX & Second bone biopsy & Second post operative year 1 & Third bone biopsy \\
\hline \multirow{3}{*}{ BMD (g/cm2) } & Spine AP & 1.099 & 1.108 & 1.151 & 1.172 \\
\cline { 2 - 6 } & Spine LAT & 0.997 & 1 & 1.148 & 1.018 \\
\cline { 2 - 6 } & Forearm & 0.475 & 0.509 & 0.535 & 0.5 \\
\hline \multirow{2}{*}{ T-score } & Spine AP & 0.4 & 0.5 & 0.9 & 1 \\
\cline { 2 - 6 } & Spine LAT & 0.8 & 3.9 & 2.5 & 1.1 \\
\cline { 2 - 6 } & Forearm & -3.1 & -2.8 & -2 & -1.7 \\
\hline
\end{tabular}


and adynamic bone disease $[25,26]$, and even now no appropriate pharmacotherapy exists for low PTH levels after surgical PTX. Minimodeling was reported to be closely related to new bone formation in patients with hypoparathyroidism [5].

This study has limitation. Thus patient's underlying tuberous scleros may be contributed to the bone abnormalities, because tuberous sclerosis can cause bone cysts or sclerotic lesions.

In conclusion, the first biopsy in our patient showed that osteitis fibrosa related to hyperparathroidism contributed to the Achilles tendon ruptures. The second biopsy showed that osteomalacia contributed to the pseudofracture of the ulna, seen as a Looser zone; the osteomalacia was related to continuation of etidronate and 1,25-dihydroxyvitamin $\mathrm{D}$ deficiency resulting from discontinuation of calcitriol in a condition of low serum levels of PTH after PTX. The third biopsy showed that resumption of calcitriol and discontinuation of etidronate improved the bone disease, despite continued low levels of PTH. This case indicates that when BPs are started in long-term HD patients with a potential vitamin $\mathrm{D}$ deficiency administration of active vitamin $\mathrm{D}_{3}$ is essential to prevent osteomalacia via mineralization disturbances.

\begin{abstract}
Abbreviations
ALP: Alkaline phosphatase; BAP: bone alkaline phosphatase; BFR/BV: bone formation rate per unit of bone volume; BMD: bone mineral density; BPs: bisphosphonates; BV/TV: trabecular bone volume to total volume; CKD: chronic kidney disease; CKD-MBD: chronic kidney disease mineral and bone disorder; DEXA: dual energy X-ray absorptiometry; ES/BS: eroded surface to bone surface; Fb.V/TV: fibrous tissue volume to total volume; HD: hemodialysis; KDIGO: Kidney Disease: Improving Global Outcomes; N.Oc/ BS: number of osteoclasts to bone surface; Ob.S/BS: osteoblasts surface to bone surface; OS/BS: osteoid surface to bone surface; O.Th: osteoid thickness; OV/BV: osteoid volume to bone volume; OV/TV: osteoid volume to tissue volume; PTH: parathyroid hormone; PTX: parathyroidectomy; ROD: renal osteodystrophy; Tb.Th: trabecular thickness; Th.W: trabecular unit wall thickness
\end{abstract}

\section{Acknowledgments}

We wish to thank Mrs. Akemi Ito (Ito Bone Science Institute, Niigata, Japan) for performing the bone histomorphometric analyses.

\section{Authors' contributions}

$\mathrm{MH}, \mathrm{IK}, \mathrm{SY}, \mathrm{MN}, \mathrm{Kl}, \mathrm{YH}, \mathrm{JH}, \mathrm{NS}$ and $\mathrm{YU}$ were involved in study design and data interpretation. $\mathrm{MH}, \mathrm{IK}, \mathrm{SY}, \mathrm{MN}, \mathrm{KI}, \mathrm{YH}, \mathrm{JH}, \mathrm{NS}$ and $\mathrm{YU}$ were involved in the data analysis. All authors critically revised the report, commented on drafts of the manuscript, and approved the final report.

\section{Funding}

No funding was obtained for this study.

\section{Availability of data and materials}

All data generated or analysed during this study are included in this published article.

\section{Declarations}

Ethics approval and consent to participate Not Applicable.

\section{Consent for publication}

Written informed consent was obtained from the patient for publication of this case report and any accompanying images. A copy of the written consent is available for review by the Editor of this journal.

\section{Competing interests}

The authors declare no competing financial interests and no conflicts of interest.

\section{Author details \\ 'Department of Orthopaedic Surgery, Toranomon Hospital Kajigaya, 1-3-1 Kajigaya, Takatsu, Kawasaki, Tokyo, Kanagawa 212-0015, Japan. ${ }^{2}$ Department of Nephrology Center, Toranomon Hospital Kajigaya, 1-3-1, Takatsu, Kawasaki, Tokyo, Kanagawa 212-0015, Japan. ${ }^{3}$ Okinaka Memorial Institute for Medical Research, Toranomon Hospital, Tokyo, Japan.}

Received: 17 November 2020 Accepted: 20 August 2021

Published online: 03 September 2021

\section{References}

1. Sprague SM, Bellorin-Font $E$, Jorgetti $V$, Carvalho AB, Malluche HH, Ferreira A, et al. Diagnostic accuracy of bone turnover markers and bone histology in patients with CKD treated by Dialysis. Am J Kidney Dis. 2016;67(4):559-66. https://doi.org/10.1053/j.ajkd.2015.06.023.

2. Moe S, Drüeke T, Cunningham J, Goodman W, Martin K, Olgaard K, et al. Improving Global Outcomes (KDIGO) Definition, evaluation, and classification of renal osteodystrophy: a position statement from kidney Disease: improving global outcomes (KDIGO). Kidney Int. 2006;69(11):194553. https://doi.org/10.1038/sj.ki.5000414.

3. Sherrard DJ, Hercz G, Pei Y, Maloney NA, Greenwood C, Manuel A, et al. The Spectrum of bone Disease in end-stage renal failure--an evolving disorder. Kidney Int. 1993;43(2):436-42. https://doi.org/10.1038/ki.1993.64.

4. Recker RR, Kimmel DB, Parfitt MA, et al. Static and tetracycline-based bone histomorphometric data from 34 normal postmenopausal females. J Bone Miner Res. 1988;3(2):133-44. https://doi.org/10.1002/jbmr.5650030203.

5. Ubara Y, Tagami T, Nakanishi S, Sawa N, Hoshino J, Suwabe T, et al. Significance of Minimodeling in Dialysis patients with Adynamic bone Disease. Kidney Int. 2005;68(2):833-9. https://doi.org/10.1111/j.1523-1755.2 005.00464.x.

6. Sumida K, Ubara Y, Hoshino J, et al. Bone histomorphometry in a long-term hemodialysis patient with hypoparathyroidism and sarcoidosis. Osteoporos Int. 2015;26(4):1435-41.

7. Pimentel A, Ureña-Torres P, Zillikens MC, Bover J, Cohen-Solal M. Fractures in patients with CKD-diagnosis, treatment, and prevention: a review by members of the European calcified tissue society and the European renal Association of Nephrology Dialysis and Transplantation. Kidney Int. 2017; 92(6):1343-55. https://doi.org/10.1016/j.kint.2017.07.021.

8. Hiramatsu R, Ubara Y, Suwabe T, Sumida K, Hayami N, Yamanouchi M, et al. Osteomalacia and insufficiency fracture in a hemodialysis patient with autosomal dominant polycystic kidney disease. Intern Med. 2012;51(23): 3277-80. https://doi.org/10.2169/internalmedicine.51.8109.

9. Kidney Disease. Improving Global Outcomes (KDIGO) CKD-MBD Work Group. KDIGO clinical practice guideline for the diagnosis, evaluation, prevention, and treatment of Chronic Kid- ney Disease-Mineral and Bone Disorder (CKD-MBD). Kidney Int Suppl. 2009;(113):S1-130.

10. Isakova T, Nickolas TL, Denburg M, Yarlagadda S, Weiner DE, Gutiérrez OM, et al. KDOQI US commentary on the 2017 KDIGO clinical practice guideline update for the diagnosis, evaluation, prevention, and treatment of chronic kidney Disease-mineral and bone disorder (CKD-MBD). Am J Kidney Dis. 2017;70(6):737-51. https://doi.org/10.1053/j.ajkd.2017.07.019.

11. Malluche $\mathrm{HH}$. The possible use of bisphosphonates in the treatment of renal osteodystrophy. Clin Nephrol. 1992;38(Suppl 1):S87-91.

12. Fan SL, Cunningham J. Bisphosphonates in renal osteodystrophy. Curr Opin Nephrol Hypertens. 2001;10(5):581-8. https://doi.org/10.1097/00041552-2001 09000-00006

13. Hamdy NA, McCloskey EV, Brown CB, et al. Effects of clodronate in severe hyperparathyroid bone disease in chronic renal failure. Nephron. 1990;56(1): 6-12. https://doi.org/10.1159/000186092.

14. Rodd C. Bisphosphonates in dialysis and transplantation patients: efficacy and safety issues. Perit Dial Int. 2001;21(Suppl 3):S256-60. 
15. Ring T, Sodemann B, Nielsen C, Melsen F, Kornerup HJ. Mineralization defect but no effect on hypercalcemia during clodronate treatment in secondary hyperparathyroidism. Clin Nephrol. 1995;44(3):209-10.

16. Gibbs CJ, Aaron JE, Peacock M. Osteomalacia in Paget's disease treated with short term, high dose sodium etidronate. Br Med J (Clin Res Ed). 1986; 292(6530):1227-9. https://doi.org/10.1136/bmj.292.6530.1227.

17. MacGowan JR, Pringle J, Morris VH, et al. Gross vertebral collapse associated with long-term disodium etidronate treatment for pelvic Paget's disease Skelet Radiol. 2000;29(5):279-82. https://doi.org/10.1007/s002560050608.

18. Watts NB, Harris ST, Genant HK, Wasnich RD, Miller PD, Jackson RD, et al. Intermittent cyclical etidronate treatment of postmenopausal osteoporosis. N Engl J Med. 1990;323(2):73-9. https://doi.org/10.1056/NEJM19900712323 0201.

19. Wolf M, Shah A, Gutierrez O, Ankers E, Monroy M, Tamez H, et al. Vitamin D levels and early mortality among incident hemodialysis patients. Kidney Int. 2007;72(8):1004-13. https://doi.org/10.1038/sj.ki.5002451.

20. Jean G, Terrat JC, Vanel T, Hurot JM, Lorriaux C, Mayor B, et al. Daily oral 25hydroxycholecalciferol supplementation for vitamin $D$ deficiency in haemodialysis patients: effects on mineral metabolism and bone markers. Nephrol Dial Transplant. 2008;23(11):3670-6. https://doi.org/10.1093/ndt/ gfn339.

21. Mac-Way F, Azzouz L, Noel C, Lafage-Proust MH. Osteomalacia induced by vitamin $D$ deficiency in hemodialysis patients: the crucial role of vitamin $D$ correction. J Bone Miner Metab. 2014;32(2):215-9. https://doi.org/10.1007/ s00774-013-0480-7.

22. Hernandez JD, Wesseling K, Boechat MI, Gales B, Salusky IB. Osteomalacia in a hemodialysis patient receiving an active vitamin $D$ sterol. Nat Clin Pract Nephrol. 2007;3(4):227-32. https://doi.org/10.1038/ncpneph0443.

23. Rodríguez-Ortiz ME, Pendón-Ruiz de Mier MV, Rodríguez M Parathyroidectomy in dialysis patients: indications, methods, and consequences. Semin Dial. 2019;32(5):444-51. https://doi.org/10.1111/sdi.12 772.

24. Schneider R, Slater EP, Karakas E, Bartsch DK, Schlosser K. Initial parathyroid surgery in 606 patients with renal hyperparathyroidism. World J Surg. 2012; 36(2):318-26. https://doi.org/10.1007/s00268-011-1392-0.

25. Lorenz K, Ukkat J, Sekulla C, Gimm O, Brauckhoff M, Dralle H. Total parathyroidectomy without autotransplantation for renal hyperparathyroidism: experience with a qPTH-controlled protocol. World $I$ Surg. 2006;30(5):743-51. https://doi.org/10.1007/s00268-005-0379-0.

26. Saunders RN, Karoo R, Metcalfe MS, Nicholson ML. Four gland parathyroidectomy without Reimplantation in patients with chronic renal failure. Postgrad Med J. 2005;81(954):255-8. https://doi.org/10.1136/pgmj.2 004.026450 .

\section{Publisher's Note}

Springer Nature remains neutral with regard to jurisdictional claims in published maps and institutional affiliations.

Ready to submit your research? Choose BMC and benefit from:

- fast, convenient online submission

- thorough peer review by experienced researchers in your field

- rapid publication on acceptance

- support for research data, including large and complex data types

- gold Open Access which fosters wider collaboration and increased citations

- maximum visibility for your research: over $100 \mathrm{M}$ website views per year

At $\mathrm{BMC}$, research is always in progress.

Learn more biomedcentral.com/submissions 